\title{
Uydu Kaynaklı Yağmur Verilerinin Hata Oranlarının Deniz Kıyılarına Olan Uzaklığa Bağı Analizi
}

\author{
Meriç YILMAZ ${ }^{1}$ \\ Muhammad AMJAD ${ }^{2}$ \\ Burak BULUT ${ }^{3}$ \\ M. Tuğrul YILMAZ ${ }^{4}$
}

ÖZ

$\mathrm{Bu}$ çalışmada, Tropical Rainfall Measuring Mission (TRMM, Tropik Yağmur Ölçme Misyonu) 3B42 v7 uydu kaynaklı aylık yağmur verileri, Meteoroloji Genel Müdürlüğü tarafından işletilen 257 adet gözlem istasyonunda 1998 - 2014 yılları arasında ölçülen yağış verilerinin aylık kümülatif toplamları kullanılarak doğrulanmıştır. İstasyon ve uydu kaynaklı yağış verilerinin uzun dönem ortalama değerleri, birbirleri arasındaki korelasyonları, aylık ortalama ve anomali bileşenlerinin standart sapmaları ile uydu verilerinin hata oranlarının standart sapmaları incelenmiştir. Uydu verilerinin hata oranlarının yüksekliğe ve kıyılara olan uzaklığa bağlı değişimi çalışmanın odak noktası olmuştur. Bulgular, özellikle uydu kaynaklı yağmur verilerinde anomali bileşeni hata oranlarının düşük kotlu bölgeler ve kıyı kesimleri için yüksek kotlu bölgeler ve iç kesimlere kıyasla çok daha yüksek olduğunu ortaya koymaktadır.

Anahtar Kelimeler: Uzaktan algılama, istasyonda ölçülen yağış, uydu kaynaklı yağış hata oran1.

\begin{abstract}
Investigation of the Dependence of Satellite-Based Precipitation Estimate Errors to Distance from the Coastline

In this study, Tropical Rainfall Measuring Mission (TRMM) 3 B42 v7 satellite based rainfall data are verified by using cumulative monthly rainfall data measured at 257 stations operated by the General Directorate of Meteorology between 1998 and 2014. Long-term
\end{abstract}

\footnotetext{
Not: Bu yazı

- Yayın Kurulu'na 25.11.2015 günü ulaşmıştır.

- 30 Eylül 2017 gününe kadar tartışmaya açıktır.

- DOI: $10.18400 /$ tekderg.306970

1 Orta Doğu Teknik Üniversitesi, İnşaat Mühendisliği Bölümü, Ankara - smeric@metu.edu.tr 2 Orta Doğu Teknik Üniversitesi, İnşaat Mühendisliği Bölümü, Ankara - amj.mani@gmail.com 3 Orta Doğu Teknik Üniversitesi, İnşaat Mühendisliği Bölümü, Ankara - bulutburakk@gmail.com 4 Orta Doğu Teknik Üniversitesi, İnşaat Mühendisliği Bölümü, Ankara - tuyilmaz@metu.edu.tr
} 
Uydu Kaynaklı Yağmur Verilerinin Hata Oranlarının Deniz Kıyılarına Olan ...

mean values of station-based and satellite-based rainfall data, correlation between them, Standard deviation of monthly average and anomaly components, and standard deviation of satellite based data error are analyzed. Variation of satellite-based data error with elevation and distance from coasts is the major focus of this study. The results show that, especially the anomaly component of satellite-based rainfall data error is much higher at low-elevation regions and coastal regions compared with high-elevation regions and interior regions.

Keywords: Remote sensing, station-based precipitation, satellite precipitation error.

\section{GİRIŞ}

Hidroloji ve su kaynakları alanlarında yapılan çalışmalarda kullanılan değişkenlerden en önemlilerinden birisi kuşkusuz yağı̧ parametresidir. Barajlarda sürdürülebilir bir şekilde üretilebilecek elektrik potansiyelinin hesaplanması, barajlarda tutulabilecek suyun hesab1, tarımsal sulamada kullanım amaçlı ayrılabilecek suyun bütçe hesabı, su rezervlerinin aylık ortalamalardan farkının hesabı, kuraklık çalışmaları ve daha birçok hidroloji ve su kaynakları ile ilgili çalışma, yüzeye düşen yăğı̧ların aylık ve yıllık miktarlarının dikkate alınması ile mümkündür [1]. Dolaylı olarak yağış miktarlarının yukarda sıralanan hidroloji ve su kaynakları uygulamalarında kullanımına uygun olacak şekilde aylık ve yıllık zaman serileri halinde incelenmesi çok kritik bir öneme sahiptir.

Yağış verileri genel bir bakışla, gözlem istasyonu ölçümleri, uzaktan algılama prensibine dayalı uydu ve radar gözlemleri ve iklim modellerinden elde edilen sonuçlar olmak üzere üç farklı yöntemle elde edilebilmektedir. İstasyonların çoğunlukla ekonomik sebeplerden ötürü seyrek kurulmasından ve bakım zorlukları sebebiyle kentsel alanlara daha yakın konumlandırılmasından dolayı, istasyonlardan elde edilen geniş ölçekli yağış verileri temsil hataları içermektedir. Buna rağmen istasyonlardan elde edilen yağış verileri genel itibariyle en güvenilir veriler olarak düşünülmekte ve uydu ve model kaynaklı verilerin doğrulanmasında birincil derecede kullanılmaktadır [2-4].

Sayısal modeller ile elde edilen yağış verileri gözlemlenmiş veriler olmadığı halde, özellikle kısa süreli tahminlerde son derece doğru sonuçlar vermektedir. Bu da, birçok gözlemlenmiş verinin asimilasyonu ile birlikte su/enerji/momentum bütçelerinin korunumuna dayanan denklemlerin doğru uygulanmasına dayanmaktadır. Ancak, sayısal iklim modelleri ile konveksiyonel yağışların tahmininde halen sorun yaşanıyor olması ve bu modellerin düşük mekansal çözünürlüğe sahip olması (genellikle $0.40^{\circ}-1.0^{\circ}$ arasında), model verilerinin çeşitli hidroloji ve su kaynakları çalışmalarında kullanımını sinırlandırmaktadır.

Uzaktan algılama prensibine dayalı ve genellikle mikrodalga bantlarında yapılan radar gözlemleri kullanılarak yüksek çözünürlükte yağış verisi elde etmek mümkündür. Ancak, radarların okyanus ve denizler üzerinde sayıca çok sinırlı olması, radarlardan elde edilen yağış verilerinin seçilen Z-R (Reflektivite-Yağış) ilişkisine olan bağl1lığının doğru elde edilememesi, topoğrafyanın sinyalleri engellemesi ve meteorolojik olmayan kaynaklardan ötürü gerçekleşen yapay ekolar nedeniyle, radar verilerinin küresel veya geniş ölçekli alanlarda kullanımı sınırlı kalmaktadır. Öte yandan, yine uzaktan algılama prensibine dayalı ve genellikle mikrodalga bantlarında yapılan uydu gözlemlerinden elde edilen yağış verileri, küresel olarak yağışın tutarlı bir şekilde elde edilmesini sağlamaktadır [5]. 
Mikrodalga temelli yağış algoritmalarının ana prensibi, yağışlardan elde edilen sinyalin gözlemlenen yüzeyden gelen sinyalden emisyon ve polarizasyon karakterlerine bağlı olarak ayrıştırılmasına dayanmaktadır. Göreceli olarak modellerden daha yüksek mekansal çözünürlükte yağmur verisi vermesi sebebiyle olsa gerek, uydu kaynaklı yağış verileri birçok su kaynakları ve hidroloji uygulamasında yaygınlıkla kullanılmaktadır. Aktif ve pasif mikrodalga gözlemlerinin birleştirilmesi ile elde edilen bu veri setlerinin en yaygınlıkla kullanılan örneklerinden birisi ise şüphesiz Tropical Rainfall Measuring Mission (TRMM, Tropik Yağmur Ölçme Misyonu) uydusu gözlemlerine [5] dayanan verilerdir. Ayrıca bu uydudan elde edilen yağmur verileri, şüphesiz şu ana kadar uydulardan elde edilen en doğru uzun zaman serilerine sahip veri setlerinden birisidir.

TRMM verisi, dünyanın değişik bölgeleri için doğrulama çalışmalarında kullanılmıştır [69]. Gerçekleştirilen bir çalışmada [6] TRMM verilerinin yer radar ağından elde edilen yağmur verilerini kullanarak analizi gerçekleştirilmiştir ve TRMM verilerinin geciken sinyallere karşı düzeltilmiş olan TRMM sinyallerinin ortalama olarak 0.91 korelasyonla radar sinyalleriyle uyumlu olduğunu göstermiştir. Bir diğer çalışmada ise [7], TRMM dahil olmak üzere birçok uydu ve model verilerinin doğrulaması ve karşılaştırması yapılmıştır. $\mathrm{Bu}$ çalışmada sonuç olarak uydu verilerinin yaz aylarında daha doğru sonuçlar verdiği ve modellerin ise kış aylarında daha doğru sonuçlar verdiği ortaya koyulmuştur.

Ülkemizdeki en önemli yer gözlem veri kaynaklarından birisi kuşkusuz Meteoroloji Genel Müdürlüğü (MGM) tarafından kurulmuş ve işletilmekte olan istasyonlardır [10]. Birçok çalışmada çok kritik önemi olmasına rağmen ülkemiz üzerinde TRMM verilerinin doğrulanmasına yönelik çalışmalar günümüze kadar çok sınırlı sayıda kalmıştır [11-12]. Bu çalışmada tüm Türkiye üzerinde 257 istasyonda elde edilen yağış gözlemleri kullanılarak TRMM uydu verilerinin 1998-2014 yılları arasında doğrulanması gerçekleştirilmiştir. Hidroloji ve su kaynakları uygulamalarını odaklayan bu çalışma yağış verilerini aylık zaman serileri şeklinde incelemiştir.

\section{2. ÇALIŞMA YÖNTEMI}

\section{1. İstasyonlarda Ölçülen Yağış Verileri}

Uydu kaynaklı verilerin hata oranlarını analiz etmek amacıyla, ülkemizin farklı bölgelerinde MGM tarafından 80 yıldır işletilen 371 adet büyük ve küçük klima istasyonlarında elde edilen gözlem verileri kullanılmıştır. Bu istasyonlarda, plüviyometreler aracılı̆̆ıyla 07:00, 14:00 ve 21:00 saatlerinde rasatlar yapılmaktadır. Bu çalışmada MGM tarafından ölçülen yağış verilerinin aylık ortalamaları kullanılmıştır. Verilerin sürekliliğinin göz önünde bulundurulduğu bir kalite kontrol gerçekleştirilmiştir ve bunun sonucunda 1998-2014 yılları arasında (17 yıl) toplamda 8 yıldan daha az verisi olan klimalar çalışmanın dışında bırakılmıştır. Bu çalışmada, veri sürekliliği sağlayabilen 257 klimanın MGM tarafından kaydedilen istasyon numaraları Çizelge 1'de sunulmaktadır. Bu istasyonlarda yapılan ölçümler hakkında detaylı bilgi Yalçın ve diğerleri (2005) tarafından verilmektedir [13]. MGM tarafindan 2004 yllından günümüze kadar yaklaşık 1305 Otomatik Meteorolojik Gözlem İstasyonu (OMGi) kurulmuş olmasına karşın, bu OMGI'lerin sayısı 2010 yılına kadar sadece 206 ile sınırlı kalmıştır. Bu sebeple 1998 yılından günümüze kadar gözlem yapan uydu verilerinin doğrulanması amacıyla klimalarda yapılan gözlemler kullanılmıştır. 
Uydu Kaynaklı Yağmur Verilerinin Hata Oranlarının Deniz Kıyllarına Olan ...

Çizelge 1. Analizlerde verileri kullanılan 257 MGM gözlem istasyon numaraları

\begin{tabular}{lllllllll}
\hline 17015 & 17086 & 17184 & 17262 & 17618 & 17695 & 17778 & 17852 & 17944 \\
17020 & 17088 & 17186 & 17265 & 17622 & 17700 & 17780 & 17854 & 17948 \\
17022 & 17089 & 17188 & 17270 & 17624 & 17702 & 17784 & 17860 & 17950 \\
17024 & 17090 & 17190 & 17275 & 17626 & 17704 & 17786 & 17862 & 17952 \\
17026 & 17094 & 17191 & 17280 & 17628 & 17712 & 17792 & 17864 & 17954 \\
17030 & 17096 & 17192 & 17282 & 17631 & 17716 & 17793 & 17866 & 17956 \\
17033 & 17097 & 17193 & 17285 & 17632 & 17718 & 17796 & 17868 & 17958 \\
17034 & 17099 & 17196 & 17287 & 17634 & 17720 & 17798 & 17870 & 17960 \\
17037 & 17100 & 17199 & 17290 & 17636 & 17722 & 17802 & 17871 & 17962 \\
17040 & 17110 & 17201 & 17292 & 17646 & 17726 & 17804 & 17872 & 17966 \\
17042 & 17111 & 17203 & 17294 & 17648 & 17728 & 17806 & 17874 & 17968 \\
17045 & 17112 & 17204 & 17296 & 17650 & 17730 & 17808 & 17880 & 17970 \\
17046 & 17114 & 17205 & 17297 & 17652 & 17732 & 17810 & 17882 & 17974 \\
17050 & 17116 & 17210 & 17298 & 17656 & 17734 & 17812 & 17884 & 17979 \\
17052 & 17119 & 17220 & 17300 & 17658 & 17736 & 17820 & 17886 & 17980 \\
17054 & 17120 & 17221 & 17310 & 17662 & 17740 & 17822 & 17890 & 17981 \\
17056 & 17123 & 17232 & 17320 & 17664 & 17742 & 17824 & 17892 & 17986 \\
17059 & 17128 & 17233 & 17330 & 17666 & 17746 & 17826 & 17898 & \\
17061 & 17129 & 17234 & 17340 & 17668 & 17748 & 17828 & 17900 & \\
17062 & 17130 & 17237 & 17351 & 17674 & 17750 & 17832 & 17902 & \\
17066 & 17135 & 17238 & 17355 & 17676 & 17752 & 17833 & 17906 & \\
17069 & 17140 & 17239 & 17370 & 17679 & 17754 & 17835 & 17908 & \\
17070 & 17145 & 17240 & 17372 & 17680 & 17756 & 17836 & 17910 & \\
17072 & 17155 & 17242 & 17375 & 17681 & 17760 & 17837 & 17912 & \\
17074 & 17160 & 17244 & 17380 & 17682 & 17762 & 17840 & 17914 & \\
17078 & 17162 & 17246 & 17602 & 17683 & 17764 & 17843 & 17920 & \\
17080 & 17165 & 17248 & 17604 & 17684 & 17766 & 17844 & 17924 & \\
17083 & 17172 & 17250 & 17606 & 17688 & 17768 & 17846 & 17926 & \\
17084 & 17175 & 17255 & 17608 & 17690 & 17774 & 17847 & 17928 & \\
17085 & 17180 & 17261 & 17610 & 17692 & 17776 & 17850 & 17936 & \\
\hline & & & & & & & &
\end{tabular}

\subsection{Uydu Kaynaklı Veriler}

TRMM, Amerikan Ulusal Havacılık ve Uzay Dairesi (NASA) ve Japon Uzay Araştırma Ajansı'nın (JAXA) ortaklaşa gerçekleştirdiği bir uzay misyonudur. Tropik yağmurların 
araştırılması ve incelenmesi amacıyla geliştirilen TRMM, aynı zamanda bu misyon için kullanılan uydunun da ismidir. TRMM uydusunun üzerinde yer alan sensörler, uydunun farklı alanlardaki araştırmalarda kullanımını mümkün kılmaktadır. Bu sensörlerden yağış radarı sadece $40^{\circ}$ kuzey ve $40^{\circ}$ güney enlemleri arasında gözlem yapmaktayken, mikrodalga ve kızılötesi görüntü elde etmekte kullanılan sensörler $50^{\circ}$ kuzey ve $50^{\circ}$ güney enlemleri arasında gözlem yapabilmektedir. Yağış radarından ve mikrodalga ve kızılötesi bantlarında ölçüm yapan sensörlerden elde edilen gözlemler birleştirilerek yağış ürünleri elde edilmektedir. $\mathrm{Bu}$ ürünler $1998^{\prime}$ den günümüze kadar $50^{\circ}$ kuzey ve $50^{\circ}$ güney enlemlerini kapsayacak şekilde $25 \mathrm{~km}$ mekansal ve 3 saatlik zamansal çözünürlükte elde edilmektedir. Bu uydu gözlemleri kullanılarak elde edilen TRMM 3B42 V7 ürünü [5] mekansal çözünürlüğü $25 \mathrm{~km}$ (orijinal gözlemlerle aynı) ve zamansal çözünürlüğü ise 1 günlük olacak şekilde sunulmaktadır. Elde edilen bu günlük TRMM 3B42 V7 ürünü ise daha sonra yazarlar tarafından aylık toplam olacak şekilde işlenmiştir. TRMM verileri hakkında ayrıntılı bilgi Huffman ve Bolvin (2014) tarafindan verilmektedir [14].

\section{3. Çalışma Alanı ve Karşılaştırmalar}

Türkiye'nin farklı bölgelerinde yer alan 257 MGM gözlem istasyonundan 1998 - 2014 yılları arasında elde edilen yağmur gözlemleri kullanılarak, TRMM uydu verilerinin doğrulanması yapılmıştır. Kullanılan istasyonların bulunduğu coğrafyaların yükseklik bakımından incelenmesi amacıyla, istasyonlar Türkiye'nin dijital yükseklik haritası üzerinde gösterilmiştir (bkz. Şekil 1). Şekil 1'de istasyonların mekansal dağılımları, yükseklik bakımından istasyonların Türkiye'yi homojen bir şekilde temsil ettiğini göstermektedir. Bu tutarlı homojen dağılıma tek istisna olarak özellikle Doğu ve Güney Doğu Anadolu'da $2500 \mathrm{~m}$ yükseklikten daha yüksekte bulunan alanlar gösterilebilir. Orografik etkenlerden dolayı artan yükseklik ile yağış artışı olağandır ve bu sebeple yüksek kotlarda elde edilen yağış değerlerinin hata oranlarının düşük kotlardaki hata oranlarına göre değişiklik göstermesi mümkündür. MGM bu yüksekliklerde gözlem yapan istasyon sayısını 2015 yllı itibariyle artırmaktadır. Fakat 2015 yılından önceki dönemlerde bu yüksekliklerde gözlem yapan istasyon sayısının azlığı, bu bölgelerde elde edilen yağış verilerinin doğruluğunun diğer bölgelerle mukayesesini gerektirmektedir.

Su kaynakları ve hidroloji konusunda, özellikle kuraklık ve taşkınların geri dönüş aralığı veya frekansına yönelik çalışmalarda aylık ortalama değerlerden sapma oranlarının elde edilmesi kritik bir öneme sahiptir. Bu sebeple, yağış zaman serileri aylık ortalama ve bu ortalamalardan sapma olarak elde edilen anomali parçalarına ayrılıp incelenmiştir. $\mathrm{Bu}$ çalışmada her bir istasyonun aylık ortalama değeri, 1998 ve 2014 yılları arasındaki 17 yıllık dönemde, her bir ay için ayrı ayrı ortalamaların hesaplanması ile elde edilmiştir. Örneklemek gerekirse, bir istasyondaki Ocak ayının ortalama değeri sadece o istasyonda elde edilmiş 17 adet Ocak ayı yağış miktarlarının ortalaması alınarak elde edilmiştir. $\mathrm{Bu}$ yöntemle, 12 ay için ayrı ortalama değerleri her istasyon için ayrı ayrı elde edilmiştir. Anomali değerleri ise, her ayın yağış miktarından o aya ait ortalama değeri çıkarılarak hesaplanmıştır. Yine örneklemek gerekirse, 17 adet Ocak ayı yağış miktarından Ocak ayının ortalama değeri çıkarılarak 17 adet anomali değeri hesaplanmıştır. Beklendiği üzere, her ay için hesaplanan 17 anomali değerinin ortalamaları sıfırdır. Her ayın anomali değerlerinin elde edilmesiyle, 257 istasyon için $12 * 17=204$ aylık zaman serileri elde edilmiştir. 


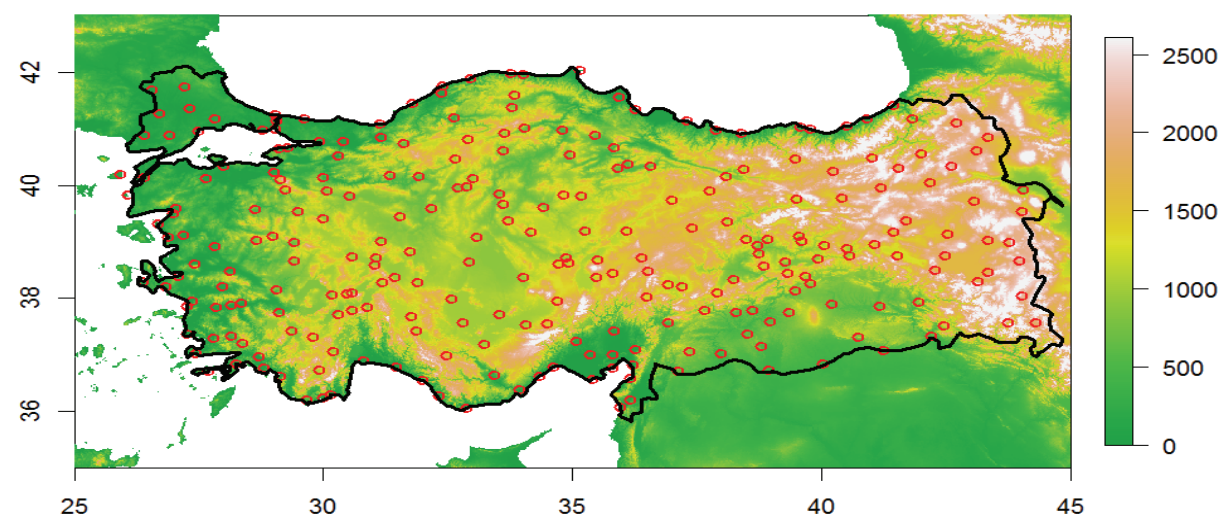

Şekil 1. İstasyonların yükseklik (m) haritası üzerinde mekansal dăğlımı

Yukarıdaki yöntemin TRMM uydu verilerine uygulanması amacıyla, her bir istasyonu içine alan hücrelerdeki günlük TRMM zaman serileri aylık TRMM zaman serilerine kümülatif toplam alınarak dönüştürülmüştür. Daha sonra, dönüştürülmüş aylık zaman serileri, yine aylık ortalama ve anomali bileşenlerine ayrılmıştır. Bu yöntemle istasyonlara benzer olarak 257 hücre için 204 aylık zaman serileri elde edilmiştir.

MGM istasyonlarında ölçülen yağış değerlerinin aylık toplamları doğru kabul edilerek, TRMM uydusundan elde edilen aylık yă̆ı̧s verilerinin hata oranları hesaplanmıştır. Aylık zaman serilerinin bileşenlerine ayrılmış olmaları göz önünde bulundurularak, 1) tüm zaman serisi, 2) aylık ortalama zaman serisi ve 3) anomali zaman serisi için hata oranları ve standart sapmaları istatistikleri ayrı ayrı hesaplanmıştır. Ayrıca, bahsi geçen üç değiş̧ik zaman serisi kullanılarak istasyon ve uydu arasındaki korelasyonlar bulunmuştur. 257 istasyon için bağımsız olarak elde edilen istatistiklerin ortalamaları alınmış ve histogram analizi vasitasıyla uydu verilerinin doğruluğuna dair genel durum değerlendirmesi yapılmıştır.

\section{BULGULAR VE TARTISSMALAR}

Tüm istasyonlardan elde edilen yer gözlem verilerinin aylık kümülatif toplam değerleri alınarak 1998-2014 yılları arasında Türkiye'deki yağışın değişimi bulunmuştur (bkz. Şekil 2). Aylık ortalama değerleri çıkarıldığında anomali değerleri kurak dönemleri (özellikle 2008 ve 2014 kuraklıklarını) ve bu kuraklıkların başlangıç ve bitiş evrelerini tüm verilere oranla daha net göstermektedir.

İstasyon ve uydudan elde edilen yağmur verileri arasındaki korelasyonlar 257 istasyon üzerinde tüm veri, aylık ortalama zaman serisi ve anomali zaman serileri için hesaplanmıștır. Bu korelasyonların histogramları Şekil 3'te sunulmaktadır. Uydu verileri ile istasyon verileri arasında, aylık ortalama değerler bazında büyük çoğunlukla 0.90 üzerinde korelasyonlar bulunurken anomali değerleri bazında korelasyonlar ağıllıklı olarak 0.80 ve 0.90 arasında olduğu görülmüsștür (bkz. Şekil 3). Bu durum, uydu kaynaklı yağış verilerinin sahip olduğu yağış sinyalinin aylık ortalama değerlere daha fazla bağlı olduğu ve tüm veri 
setine kıyasla anomali değerlerinin daha düşük doğruluk payına sahip olduğu sonucunu ortaya koymaktadır. Tüm veri, aylık ortalama zaman serisi ve anomali zaman serisi için elde edilen 257 korelasyon değerinin ortalamaları ile hata standart sapmalarının sunulduğu Çizelge 2'de, yukarıda bahsedilen durum daha net görülmektedir.
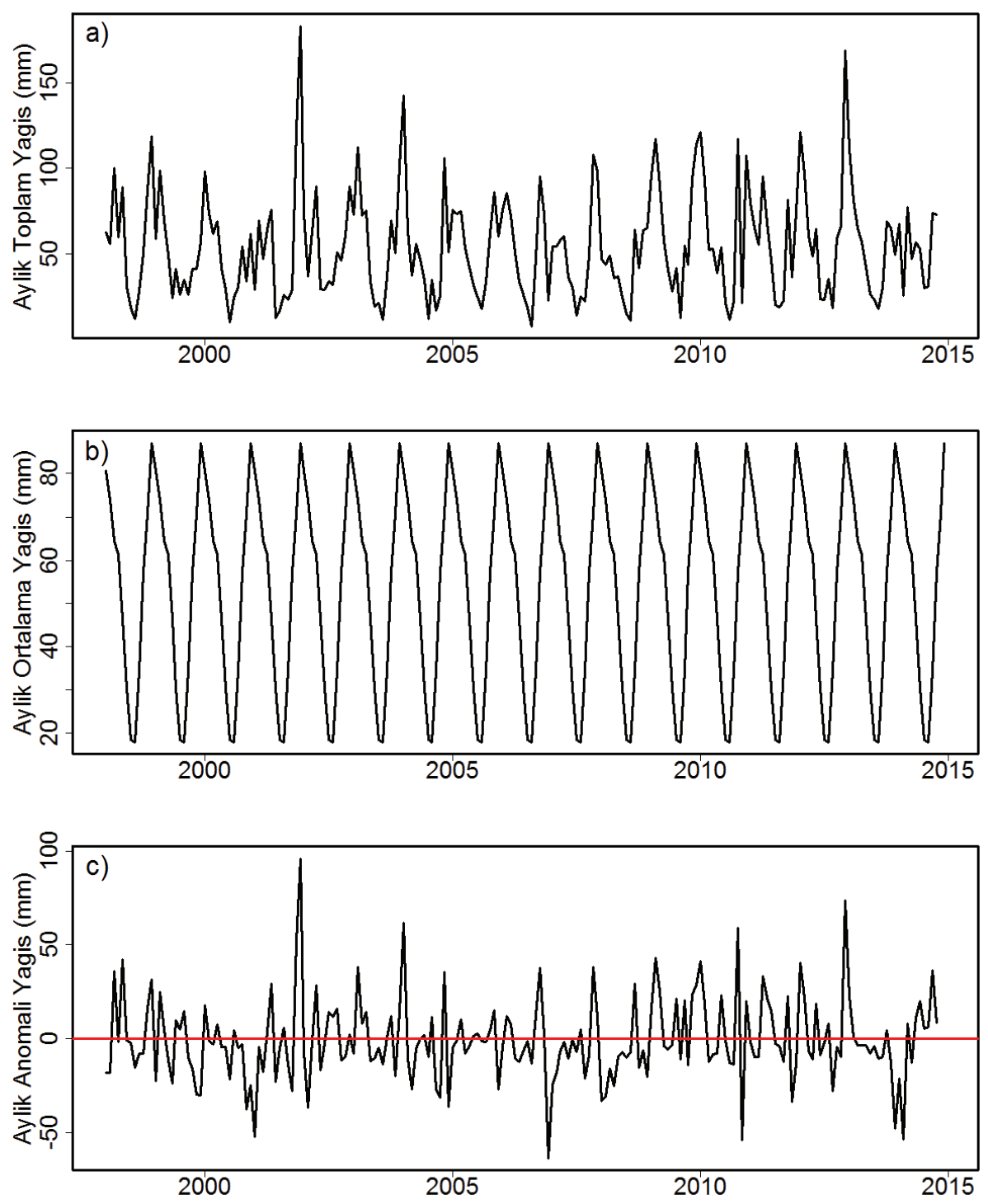

Şekil 2. Toplam 257 istasyon üzerinde ölçülen a) toplam yă̆ış, b) aylık ortalama ve c) anomali zaman serileri 
Uydu Kaynaklı Yağmur Verilerinin Hata Oranlarının Deniz Klyılarına Olan ...
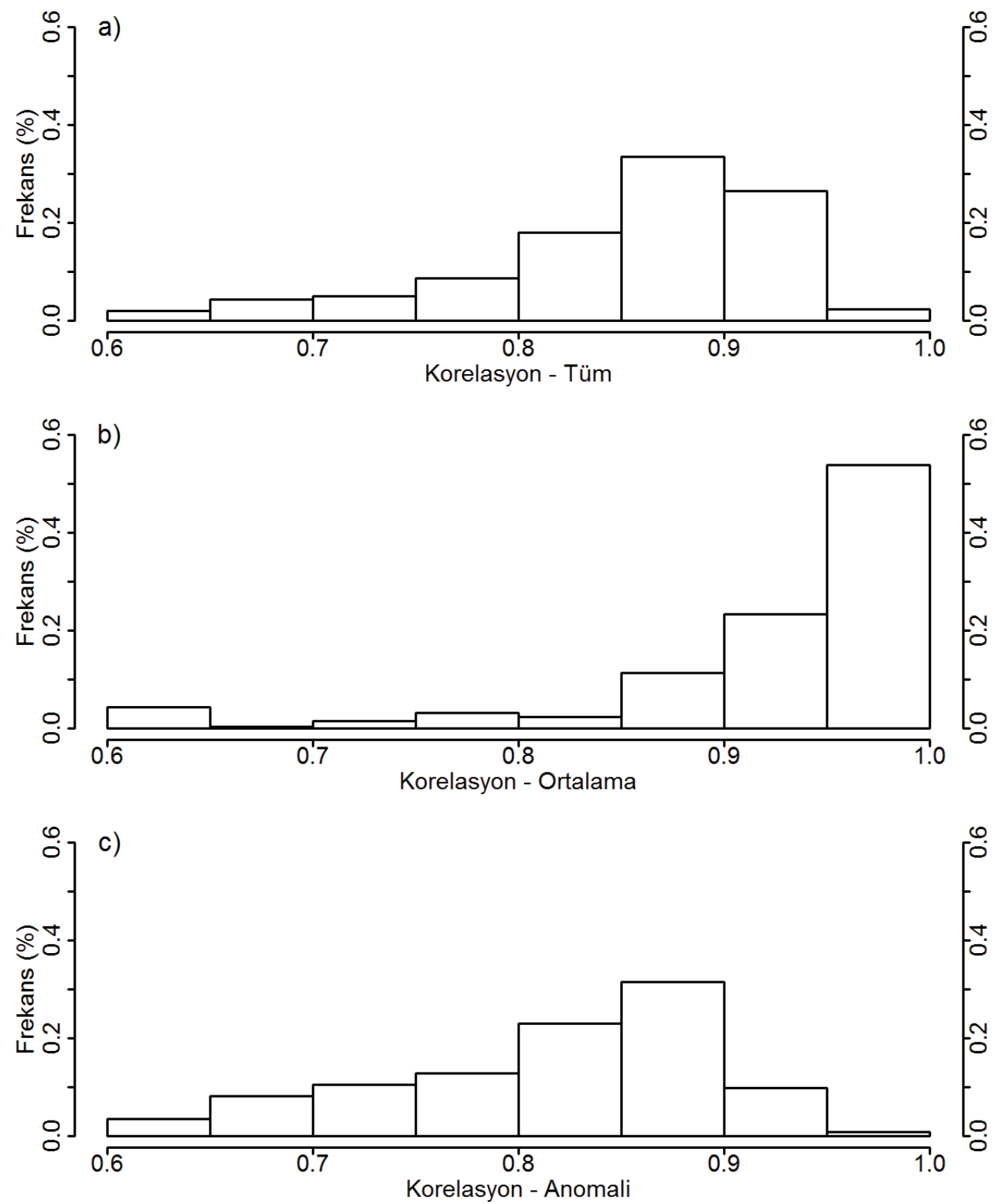

Şekil 3. Ístasyon ve uydudan 1998 - 2014 yılları arasında elde edilmis aylık yağmur verilerinin 257 istasyon üzerindeki korelasyonlarının a) tüm veri, b) ortalama ve c) anomali kısımlarına göre frekans dağılımı 
Meriç YILMAZ, Muhammad AMJAD, Burak BULUT, M. Tuğrul YILMAZ

Çizelge 2. İstasyon ve uydudan 1998 - 2014 yılları arasinda elde edilmiş ayllk yağmur verilerinin 257 istasyon üzerinde ortalama korelasyonlarl, uydu verilerinin ortalama hata standart sapmasl ve hata ortalamasl

\begin{tabular}{lccc}
\hline & Tüm & $\begin{array}{c}\text { Aylık } \\
\text { Ortalama }\end{array}$ & Anomali \\
\hline Korelasyon [-] & 0.85 & 0.91 & 0.81 \\
Hata Stand. Sapması [mm] & 28.23 & 13.61 & 24.98 \\
Hata Ortalamas1 [mm] & 4.02 & 3.02 & 0.90 \\
\hline
\end{tabular}

Uydu verileri ile istasyon verileri arasındaki lineer ilişkiyi gözlemlemek amacıyla yukarıda elde edilen korelasyon değerleri hesaplanmıştır. Toplamda 204 (12 ay*17 yıl) veri ile hesaplanan korelasyon değerlerinin istatistiksel olarak anlamlı olabilmesi için yaklaşı olarak 0.14 (Fisher denklemi kullanarak hesapland1, kabaca $2 / \sqrt{204}=0.14$ ) korelasyon değerini geçmesi gerekmektedir. Çizelge 2'de sunulan korelasyon değerlerinin 0.80 'den daha büyük olması, elde edilen korelasyon değerlerinin istatistiksel olarak anlaml olduğunu göstermektedir. $\mathrm{Bu}$ çizelgede anomali hata ortalamasının 0 çıkmamasının ve 0.90 gibi küçük bir sayı çıkmasının nedeni, zaman serisi bakımından eksik istasyon verilerine (ortalama olarak istasyonlar üzerinde 166 aylık veri bulunurken 38 aya karşıllk gelen veriler eksiktir) karşılık gelen uydu verileri hata hesaplanmasında kullanılmazken uydu istatistiklerinin hesaplanmasında kullanılmasıdır. Bu durum bahsi geçen eksik istasyonlara karşılık gelen uydu verilerinin tüm analizlerden çıkarılmasıyla giderilebilir. Fakat daha az veri kullanılması çalışmada hesaplanan istatistiklerin (örneğin standart sapma değerleri) örnekleme hatalarının da artmasına sebebiyet verecektir. Bu sebeple hesaplanan istatistiklerin örnekleme hatalarının azaltılması için bu veriler analizlerden çıkarılmamıştır.

Uydu verilerinin istasyon verilerine kıyasla yanlı olup olmadığını gözlemlemek içinse, istasyon ve uydudan elde edilen aylık kümülatif yağış değerleri ile birlikte tüm veri ve aylık ortalama/anomali bileşenlerinin standart sapmaları hesaplanmıştır. İstasyon ve uydu verilerinden hesaplanan ortalama yağış karakteristikleri Çizelge 3’te sunulmuştur. Aylık yağış verilerinin uzun dönem ortalamaları kıyaslandığında, istasyon ve uydu verileri arasındaki farkın \%1'den daha az olduğu gözlenmiş̧ir. Dolayısıyla, uydudan elde edilen yağış verileri, havzalara düşen yıllık yağışların toplam hacimlerini hesaplamada güvenle kullanılabilir. Ancak, uydu verilerinin ortalama standart sapması 204 aylık tüm veri dikkate alındığında istasyonlardan \%4 oranında daha düşük olduğu görülmektedir (bkz. Çizelge 3). Öte yandan yapılan anova testlerinde bu fark istatistiksel olarak anlaml bulunmamıştır. Ortalama standart sapmalar aylık ortalama ve anomali bileşenlerine ayrıldığında, bu farkın ağırlıklı olarak anomali (\%7 fark) kaynaklı olduğu görülmektedir. Ortalama standart sapmalar arasındaki fark, aylık ortalama bileşende çok daha düşük seviyelerdedir (\%3). Uydu verilerinin ortalama standart sapma değerlerinin istasyonlara kıyasla düşük olması, kıyı (daha yüksek yağış alan) kesimlerdeki daha kuru ve iç (daha düşük yăğş alan) kesimlerdeki daha islak verilerle de örtüşmektedir. Tüm veriler dikkate alındığında ortalama standart sapmalar arasında bulunan \%4'lük farkın, hatalı bir sonuç çıkarımına yol açıp açmayacağı ise tamamen uygulamaya bağlıdır. Standart sapmalar arası farkın büyüklükçe önemli olduğu çalışmalarda, elde edilen fark normalleştirilebilir. Dolayısıyla, elde edilen fark, birçok çalışmada (özellikle zamansal olarak ortalamadan 
Uydu Kaynaklı Yağmur Verilerinin Hata Oranlarının Deniz Kıyılarına Olan ...

sapma analizlerini içeren kuraklık gibi uygulamalarda) hatalı bir değerlendirmeye yol açmayacaktır.

Çizelge 3. İstasyon ve uydudan 1998 - 2014 yılları arasında tüm istasyonların üzerinde elde edilmiş aylik yağmur verilerinin istatistikleri

\begin{tabular}{lcc}
\hline Yağış İstatistikleri (mm) & İstasyon & TRMM \\
\hline Ortalama (tüm) & 56.36 & 56.31 \\
Stand. Sapma (tüm) & 47.85 & 45.65 \\
Stand. Sapma (aylık ortalama) & 28.89 & 28.07 \\
Stand. Sapma (anomali) & 38.26 & 35.51 \\
\hline
\end{tabular}

Uydu verilerinin hata standart sapmalarının yüksekliğe bağlı dağılımı ise Şekil 4'te gösterilmektedir. Bu şekilde, $500 \mathrm{~m}$ kotundan daha düşük bölgelerde elde edilen TRMM uydu verilerinin hata oranlarının, yüksek kotlu bölgelerden kayda değer oranda fazla olduğu açıkça görülmektedir. Daha yüksek kotlarda ise belirli bir seyir görülmemektedir. Düşük kotlarda hataların daha yüksek olması, uydu verilerinin 25 km'lik çözünürlükteki hücrelerinin sahil şeritlerinde deniz-kara ayrımı açısından homojen olmamasından ve bu sebeple deniz ve kara üzerinde kullanılan farklı yağmur elde etme algoritmalarının homojen olmayan bu hücreler üzerinde daha yüksek hata içermesinden kaynaklandığı düşünülmektedir. $\mathrm{Bu}$ sebeple, hata standart sapmalarının kıyıya olan uzaklıkla (derece cinsinden uzaklık elde edilmiştir, $1^{\circ} \sim 100 \mathrm{~km}$ ) ilişsisi Şekil 5 'te görülmektedir. TRMM hücrelerinin $25 \mathrm{~km}$ çözünürlükte olduğu göz önünde bulundurulduğunda, yeşil ile gösterilen en yüksek hata oranlarının kıyıya $0.25^{\circ}(\sim 25 \mathrm{~km})$ uzaklıktan daha yakın olan bölgelere, yani hem kara hem de deniz bölgesi içeren TRMM hücrelerine ait olduğu ortaya çıkmaktadır. TRMM yağmur elde etme algoritmaları deniz üzerinde deniz/kara emisyonu farkına dayanan bir metodoloji kullanırken kara üzerinde saçılma temeline dayanan bir algoritma kullanmaktadır [15]. Dolayısıyla, karasal alanların deniz alanlarına göre daha az olduğu ve deniz yağmur algoritmasının kullanıldığ 1 hücrelerde deniz/kara emisyon farkından dolayı hata oranlarının artmasının, kıyıya yakın bölgelerdeki yüksek hata oranlarına yol açtığı düşünülmektedir. Hataların kıyı kesimlerde artışı anomali değerlerinde daha fazla görünürken aylık ortalama değerlerde artışın daha az olduğu görülmüştür.

TRMM uydu verilerinin hata oranları şüphesiz bu verinin düşük mekansal çözünürlüğü $(25 \mathrm{~km})$ ile ilintilidir. Bu verilerden daha yüksek çözünürlüklü yağış verilerinin elde edilmesi değişik yöntemlerin kullanılması ile mümkün olabilir. Fakat elde edilecek olan yüksek çözünürlüklü yağış verilerinin doğruluk oranları, kullanılan yöntemlerin ve yapılan varsayımların doğruluğuna bağlıdır. Şayet kullanılan yöntemlerin teorisi ile uyumlu veri kullanılırsa, daha yüksek doğrulukta ve çözünürlüklü yağış verisi elde edilmesi mümkündür. 


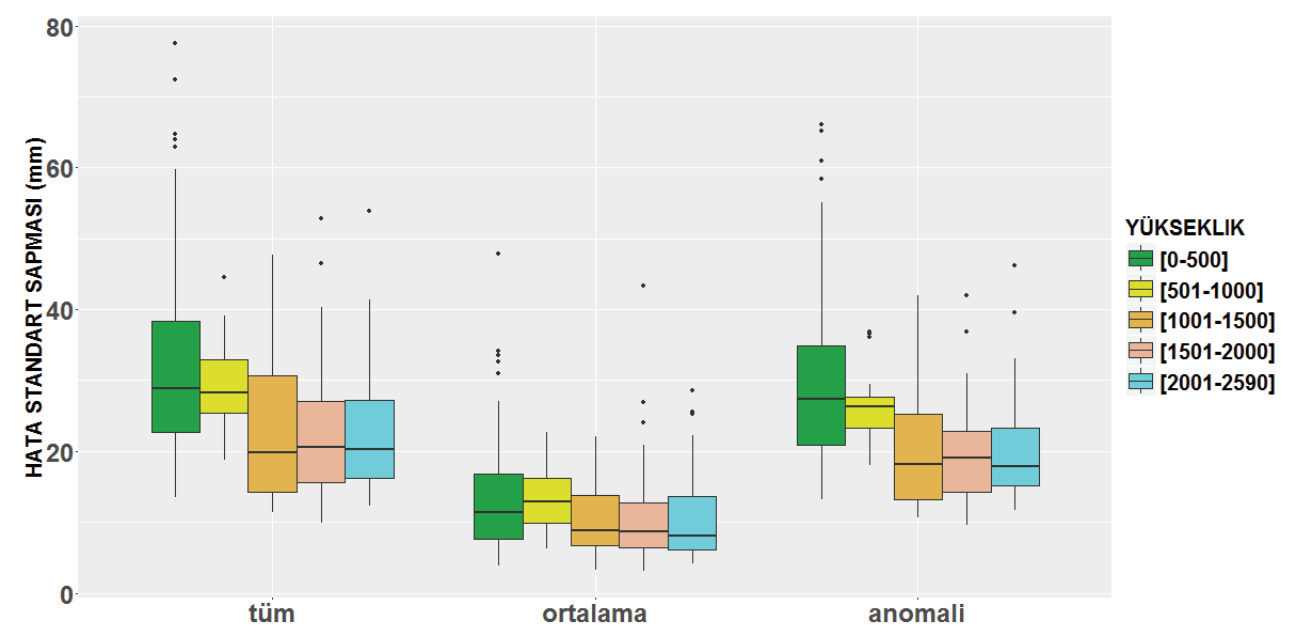

Sekil 4. İstasyon ve uydudan 1998 - 2014 yllarl arasında 257 istasyon üzerinde elde edilen hata standart sapmalarının tüm veri, ortalama ve anomali kisımlarına göre yükseklik (m) haritasındaki dağılımı

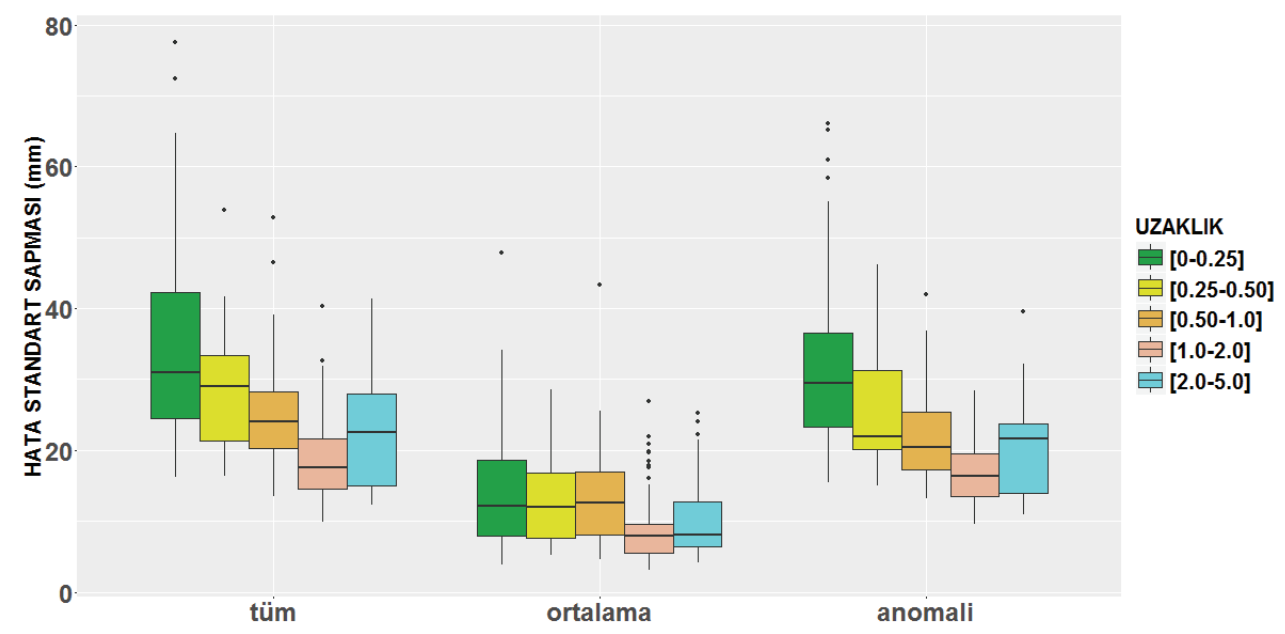

Şekil 5. İstasyon ve uydudan 1998 - 2014 yılları arasında 257 istasyon üzerinde elde edilen hata standart sapmalarının tüm veri, ortalama ve anomali kisımlarına göre klylya (Akdeniz veya Karadeniz) olan uzakllkla (uzaklık ${ }^{\circ}$ biriminde verilmiştir; $1^{\circ}$ enlem fark yaklaş̧ı $100 \mathrm{~km}$ uzaklığa karşıllı gelmektedir) 
Uydu Kaynaklı Yağmur Verilerinin Hata Oranlarının Deniz Kıyılarına Olan ...

\section{SONUÇ}

Bu çalışmada TRMM 3B42 V7 veri seti istasyonlarda ölçülen yağmur verileri ile karşılaş̧ırılmıştır. Ortalama olarak uydu verilerinin yansız ve istasyonlardan elde edilen verilerle yüksek lineer ilişki içinde olduğu bulunmuştur. Tüm veri, aylık ortalama ve anomali değerleri için ayrı ayrı yapılan karşılaştırma sonucu ile uydu verisinden elde edilen yağmur ürününün kullanılacağ çalışmanın amacına göre hata oranları elde edilmiştir. $\mathrm{Bu}$ sonuçlar uydu verilerinin bilhassa istasyonlarla ölçülmesi güç bölgelerdeki yağmur verilerinin kullanımını gerektiren çalışmalarda rahatlıkla kullanılabilirliğini göstermektedir. Öte yandan sahil şeritlerindeki hata oranlarının daha yüksek bölgelere kıyasla daha fazla olması, bu bölgelerde yapılacak çalışmalarda bu hata oranı farkının mutlak suretle göz önünde bulundurulması gerekliliğini ortaya koymaktadır.

\section{Kaynaklar}

[1] Yildiz, O. Spatiotemporal Analysis of Historical Droughts in the Central Anatolia, Turkey. Gazi University Journal of Science (GU J Sci), Vol. 27, No. 4, 1177-1184, 2014.

[2] Widmann, M. ve Bretherton, C. S., Validation of Mesoscale Precipitation in the NCEP Reanalysis Using a New Gridcell Dataset for the Northwestern United States. J. Climate, 13, 1936-1950, 2000.

[3] Thiemig, V., Rojas, R. Zambrano-Bigiarini, M., Levizzani, V., ve De Roo, A., Validation of Satellite-Based Precipitation Products over Sparsely Gauged African River Basins. J. Hydrometeor, 13, 1760-1783, 2012.

[4] Yatagai, A., Kamiguchi, K., Arakawa, O., Hamada, A., Yasutomi, N., ve Kitoh, A., APHRODITE: Constructing a Long-Term Daily Gridded Precipitation Dataset for Asia Based on a Dense Network of Rain Gauges. Bull. Amer. Meteor. Soc., 93, 1401$1415,2012$.

[5] Huffman, G.J., Adler, R.F., Bolvin, D.T., Nelkin, E.J., The TRMM Multi-satellite Precipitation Analysis (TMPA). Chapter 1 in Satellite Rainfall Applications for Surface Hydrology. Springer Verlag, ISBN: 978-90-481-2914-0, 3-22, 2010.

[6] Islam, T., Rico-Ramirez, M. A., Han, D., Srivastava, P. K., Ishak, A., M., Performance evaluation of the TRMM precipitation estimation using ground-based radars from the GPM validation network, Journal of Atmospheric and SolarTerrestrial Physics, Volume 77, 194-208, 2012.

[7] Ebert E. E., Janowiak J. E., Kidd, C., Comparison of near real time precipitation estimates from satellite observations and numerical models. Bull. Amer. Meteor. Soc. 88, 47-64, 2007.

[8] Tian Y, Peters-Lidard CD, Choudhury BJ, Garcia M, Multitemporal analysis of TRMM based satellite precipitation products for land data assimilation applications. J. Hydrometeor. 8, 1165-1183, 2007. 
[9] Ochoa, A., Pineda, L., Crespo, P. Ve Willems, P., Evaluation of TRMM 3B42 precipitation estimates and WRF retrospective precipitation simulation over the Pacific-Andean region of Ecuador and Peru. Hydrology and Earth System Sciences, 18, 3179-3193, 2014.

[10] Sönmez, I., Quality control tests for western Turkey Mesonet. Meteorological Applications, 20, 330-337, 2013.

[11] Derin, Y., ve Yilmaz, K. K., Evaluation of Multiple Satellite-Based Precipitation Products over Complex Topography. J. Hydrometeor, 15, 1498-1516 2014.

[12] Özcan, O., Musaoğlu, N., Bookhagen, B., Örmeci, C., Uydu ve yersel yağış verilerinin noktasal frekans analizi ile mekansal değerlendirmesi. TMMOB Coğrafi Bilgi Sistemleri Kongresi, Ankara, 2013.

[13] Yalçın, G., Demircan, M., Ulupınar, Y., Bulut, E.. Klimatoloji - 1. Çevre ve Orman Bakanlığı Devlet Meteoroloji İşleri Genel Müdürlüğü Ankara, Mart - 2005, DMI Yayınları, Yayın no : 2005 / 1, 2005.

[14] Huffman, G.J., ve Bolvin, D.T., TRMM and Other Data Precipitation Data Set Documentation, ftp://precip.gsfc.nasa.gov/pub/trmmdocs/3B42_3B43_doc.pdf, 2014. 
